\title{
Feeding ecology of Liophis reginae semilineatus (Serpentes: Colubridae: Xenodontinae) in Eastern Amazon, Brazil
}

\author{
Luiz Paulo P. Albarelli \& Maria C. Santos-Costa
}

\begin{abstract}
Laboratório de Ecologia e Zoologia de Vertebrados, Instituto de Ciências Biológicas, Universidade Federal do Pará. Caixa Postal 479, 66075-110 Belém, Pará, Brasil. E-mail: albarelli2000@yahoo.com.br
\end{abstract}

\begin{abstract}
We studied the diet of Liophis reginae semilineatus (Wagler, 1824) from eastern Amazon, Brazil, based on the analysis of 182 preserved specimens. Thirty-six individuals had prey in their stomachs; 34 (95\%) contained exclusively anurans and $2(5 \%)$ contained both anurans and lizards. The most common prey items were small Leptodactylus sp. (33.3\%), followed by Physalaemus ephippifer (Steindachner, 1864) (10.3\%). Prey ingested head-first (78\%; n = 25) were significantly larger than prey ingested tail-first $(22 \% ; n=7)$. Females of $L$. reginae semilineatus have longer and wider heads than conspecific males with the same body length, which correspond to sexual divergences in the diet (size of the prey). No correlation was found between snake head length vs. prey size (SVL, width and mass). Liophis reginae semilineatus is an anurophagous snake that probably forages actively on the ground.
\end{abstract}

KEY WORDS. Anurophagous; diet; Neotropical; snake.

Liophis Wagler, 1830 belongs to Xenodontini and includes 35 species, occurring from the Antilles and continental Central America to southern South America (DIXON 1989). Even though most species are terrestrial, some have semi-aquatic habits. Species can be found in humid environments such as primary and secondary forests, flooded forests and floodplains, as well as in dry habitats such as semi-arid scrubland and open pastures (Dixon 1980, CunHa \& NASCIMENTO 1993).

The species of Liophis are opisthodont, eating a varied diet that consists primarily of anurans (including tadpoles), in addition to earthworms, fishes, salamanders, amphisbaenids and lizards (Duellman 1978, VitT \& Vangilder 1983, Michaud \& Dixon 1989, Cunha \& Nascimento 1993, Martins \& Oliveira 1998, Pinto \& Fernandes 2004, Pizzatto \& Marques 2006).

The terrestrial L. reginae semilineatus (Wagler, 1824) is distributed in Brazil, Ecuador, part of Venezuela, Colombia, Bolivia, and Peru. In Brazil, this diurnal species can be found in the Amazon Forest and in the Atlantic Forest up to the northeast of the state of São Paulo (CunHA \& NASCIMENTO 1993), being common in anthropically disturbed areas (CunHA \& NASCIMENTO 1978) and occurrying in wet environments such as streams ("igarapés"), fresh-water springs, and ponds with emergent grasses in primary and secondary forests. The diet of $L$. reginae semilineatus consists primarily of anurans, fishes and lizards (Cunha \& Nascimento 1993, Martins \& Oliveira 1998).

Despite the fact that L. reginae semilineatus is common in the Amazon region, particularly in disturbed environments, data on the natural history of this species in the region is available only in Cunha \& Nascimento (1993) and Martins \& Oliveira (1998). In order to increase our knowledge of the natural his- tory of $L$. reginae semilineatus, this study performs a quali-quantitative analysis of the feeding biology of eastern Amazonian populations of this species.

\section{MATERIAL AND METHODS}

We examined 182 preserved specimens of L. reginae semilineatus from eastern Amazon, Pará, Brazil (96 males and 86 females). All specimens used for the analyses, collected between 1968 and 2005, are deposited in the Coleção Herpetológica of the Museu Paraense Emílio Goeldi (Appendix I).

The stomach contents of all dissected specimens were preserved in $70 \%$ ethanol and each was deposited in the same collection, under the same record number as its source.

The average temperature in eastern Amazon ranges between 24 and $27^{\circ} \mathrm{C}$ and annual average precipitation varies from approximately 1,500 $\mathrm{mm}$ to more than 3,000 mm (NHM 2007). A rainy season occurs from December to April with monthly precipitation of $300 \mathrm{~mm}$, and a dry season occurs from June to November with monthly precipitation of $88 \mathrm{~mm}$. The region has yellow and red-yellow latossoil that was originally covered by tropical rainforest. Presently, most of the area is disturbed (NHM 2007).

Data collection: we collected and recorded our data in the following manner: first, we recorded the snout-vent length (SVL, mm), head width (HW, mm, at widest part of head) and head length (HL, mm, from back of parietal to tip of snout) of each specimen. Next, we dissected each specimen in order to remove and sort out its stomach contents. Following preliminary sorting, we identified each intact or partially digested prey 
to the lowest possible taxonomic level, and determined the direction of ingestion (head-first or tail-first). Additionally, we measured the SVL, width and mass of each intact prey specimen. For digested prey, we estimated prey size based on anatomic parts using a regression analysis (ZAR 1999).

Statistical analysis: we performed all of our statistical tests using SYSTAT 10. In all cases, the Kolmogorov-Smirnov test was applied to test for a normal distribution prior to parametric tests. The level of significance adopted for all tests was 0.05 . To compare the SVL of prey ingested in different directions, an ANCOVA was used ( $\log 10$ snake SVL as co-variant, directions of ingestion as factor and $\log 10$ prey SVL as dependent variable). A reduced major axis regression was used to determine the relationships among prey dimensions (mass, SVL and width, $\log 10$ transformed) and snake head length (HL, log10 transformed), because there was no clear dependent-independent relationship between these variables (SOKAL \& RoHLF 1981). To test for the presence of sexual dimorphism, the following tests were used: ANCOVA for the measures of HL and HW (with SVL as co-variant and sex as factor); the Chi-square test to compare differences in diet composition among the sexes; MANCOVA (snake SVL as co-variant, sex as factor and mass, width and SVL of the prey as dependent variables), together with an univariate $\mathrm{F}$ test to verify differences between prey dimensions among the sexes (ZAR 1999).

\section{RESULTS}

A total of 182 individuals of L. r. semilineatus were analyzed. Of these, only 36 (19.78\%) contained 40 identifiable prey items. Seventeen snakes were males and 19 were females. Among the 36 individuals that contained prey, 34 (95\%) contained exclusively anurans, and 2 (5\%) contained both anurans and lizards (Table I).

The most common anurans found in the stomach contents were members of the Leptodactylidae (six species), Bufonidae (two species), Hylidae (two species) and Microhylidae (one species). Besides anurans, two lizards of Gymnophthalmidae (two species) were also found.

A small sized anuran, Leptodactylus sp. was ingested by $10(27.8 \%)$ of the snakes, representing $33.3 \%$ of all the prey consumed, followed by Physalaemus ephippifer (Steindachner, 1864 ) ingested by four snakes (11.1\%), representing $10.3 \%$ of all recorded preys (Table I).

Most snakes $(88.2 \% ; \mathrm{n}=30)$, had only one food item in the stomach. Three specimens had two and only one specimen had three items - 1 Scinax nebulosus (Spix, 1824) and 2 Leptodactylus sp. The stomach of one snake had 128 leptodactylid eggs, each egg approximately $1.5 \mathrm{~mm}$ diameter (Tab. I).

With respect to the direction of ingested prey, most prey items $(78 \% ; n=25)$ were ingested head-first, with prey SVL ranging from 3.3 to $12.3 \%$ (average $7.6 \%$ ) of the snake SVL, while the other $22 \%(n=7)$ were ingested tail-first, with prey SVL ranging from $2.6 \%$ to $10.4 \%$ (average $5.1 \%$ ) of the snake SVL. Prey ingested head-first were significantly larger than prey ingested tail-first (ANCOVA: $\mathrm{F}_{1,29}=6.308, \mathrm{p}=0.018$ ). Significance was not verified among the snake HL vs. prey measurements (prey mass: $\mathrm{n}=34, \mathrm{r}^{2}=6.751 \mathrm{e}-03, \mathrm{p}>0.05$, prey SVL: $\mathrm{n}=34, \mathrm{r}^{2}=$ $0.035, \mathrm{p}>0.05$, and prey width: $\mathrm{n}=34, \mathrm{r}^{2}=7.013 \mathrm{e}-03, \mathrm{p}>0.05$ ).

Our results on sexual dimorphism indicate that adult females of L.r.semilineatus were larger than adult males in head length (ANCOVA: $\mathrm{F}_{1,108}=11.090, \mathrm{p}<0.01$ ) and head width (ANCOVA: $\mathrm{F}_{1,108}=7.352, \mathrm{p}<0.01$ ). Despite this difference, however, no significant discrepancies were found in the diet composition of males and females $\left(\chi^{2}=20.46 ; \mathrm{p}=0.11\right)$. Additionally, the MANCOVA test revelaed differences in prey dimensions between the sexes that are independent from the predators' SVL (Wilks' lambda $=0.029, \mathrm{p}<0.01$ ). The F test revealed significant differences in all prey measurements between sexes, with females ingesting larger preys than males (prey mass: $\mathrm{F}_{3,28}=16.98, \mathrm{p}<0.01$; prey SVL: $\mathrm{F}_{3,28}=123.25$, $\mathrm{p}<0.01$; prey width: $\mathrm{F}_{3,28}=104.27$ MANCOVA, $\left.\mathrm{p}<0.01\right)$.

\section{DISCUSSION}

Liophis reginae semilineatus is a predominantly anurophagous snake, like most snakes of this genus (VITT 1983, VITT \& Vangilder 1983, Michaud \& Dixon 1989, Pinto \& Fernandes $2004)$, that occasionally preys upon other animals such as lizards. Our findings are consistent with previous reports that confirm the presence of anurans and lizards in the diet of this snake (Cunha \& Nascimento 1993, Martins \& Oliveira 1998). Additionally, we have found anuran eggs in the diet of L. reginae semilineatus. Anuran egg predation had been previously reported for Liophis jaegeri (Günther, 1858) (SOLÉ \& KWET 2003). Feeding on a large quantity of eggs and tadpoles may be advantageous, because it may result in the comsumption of a large quantities of prey in a short period of time, with little exposure to predation. Even though we did not find any fish in our samples, this item had been previously reported as prey by CunHa \& NASCIMENTO (1993).

The use of anurans (Leptodactylus andreae Müller, 1923, Leptodactylus wagneri (Peters, 1862), Allobates sp.) and lizards (Cercosaura ocellata Wagler, 1830) as prey had been previously reported for different areas of the Amazon (Duellman 1978, Ávila-Pires 1995, Martins \& Oliveira 1998). However, variations in diet composition among populations from these areas may be a result of sampling biases caused by the geographical distribution patterns of the prey, for example.

Liophis reginae semilineatus is active during the day (CuNHA $\&$ NASCIMENTO 1978), while most of the prey consumed is nocturnal (with the exception of lizards) and can be found by foraging the ground (Duellman 1978, Ávila-Pires 1995, Ávila-Pires \& Hoogmoed 1997, Estupiñan et al. 2002, Lima et al. 2006). Based on this information, we conclude that our subject forages the ground predominantly during the day seeking for inactive (frogs) or active prey (lizards). 
Table I. Food items and their frequency in the diet of $L$. reginae semilineatus from eastern Amazon, Pará. $\left({ }^{*}\right)$ The Leptodactylidae eggs $(n=128)$ were considered as a single food item.

\begin{tabular}{|c|c|c|c|c|}
\hline \multirow{2}{*}{ Prey taxa } & \multicolumn{2}{|c|}{ Snakes with prey items } & \multicolumn{2}{|c|}{ Prey items } \\
\hline & $\mathrm{n}$ & $\%$ & $\mathrm{n}$ & $\%$ \\
\hline \multicolumn{5}{|l|}{ Amphibia } \\
\hline \multicolumn{5}{|l|}{ Leptodactylidae } \\
\hline Leptodactylus sp. & 11 & 27.78 & 13 & 33.33 \\
\hline Leptodactylus fuscus (Schneider, 1799) & 1 & 2.78 & 1 & 2.56 \\
\hline Leptodactylus macrosternum Miranda-Ribeiro, 1926 & 1 & 2.78 & 1 & 2.56 \\
\hline Leptodactylus mystaceus (Spix, 1824) & 1 & 2.78 & 1 & 2.56 \\
\hline Physalaemus ephippifer (Steindachner, 1864) & 4 & 11.11 & 4 & 10.26 \\
\hline Physalaemus sp. & 3 & 8.33 & 3 & 7.69 \\
\hline Tadpoles & 1 & 2.78 & 1 & 2.56 \\
\hline Eggs & 1 & 2.78 & $1^{*}$ & 2.56 \\
\hline Unidentifiable Leptodactylidae & 2 & 5.56 & 2 & 5.13 \\
\hline \multicolumn{5}{|l|}{ Hylidae } \\
\hline Scinax nebulosus (Spix, 1824) & 3 & 5.56 & 3 & 7.69 \\
\hline Scinax $x$-signatus (Spix, 1824) & 2 & 5.56 & 2 & 5.13 \\
\hline Unidentifiable Hylidae & 2 & 5.56 & 2 & 5.13 \\
\hline \multicolumn{5}{|l|}{ Bufonidae } \\
\hline Rhinella margaritifera (Laurenti, 1768) & 2 & 5.56 & 2 & 5.13 \\
\hline Rhinella marina (Linnaeus, 1758) & 1 & 2.78 & 1 & 2.56 \\
\hline \multicolumn{5}{|l|}{ Microhylidae } \\
\hline Elachistocleis ovalis (Schneider, 1799) & 1 & 2.78 & 1 & 2.56 \\
\hline \multicolumn{5}{|l|}{ Lacertilia } \\
\hline \multicolumn{5}{|l|}{ Gymnophthalmidae } \\
\hline Colobosaura modesta (Reinhardt \& Luetken, 1862) & 1 & 2.78 & 1 & 2.56 \\
\hline Leposoma percarinatum (Müller, 1923) & 1 & 2.78 & 1 & 2.56 \\
\hline Total & 36 & 100 & 40 & 100 \\
\hline
\end{tabular}

The anurans identified in the stomach content of $L$. reginae semilineatus (Rhinella marina (Linnaeus, 1758), $R$. margaritifera (Laurenti, 1768), Leptodactylus fuscus (Schneider, 1799), L. macrosternum Miranda \& Ribeiro, 1926, L. mystaceus (Spix, 1824) and Physalaemus ephippifer (Steindachner, 1864)) are abundant in anthropogenic environments (EsTUPIÑ̃̃N \& Galatti 1999, Lima et al. 2006). The apparent abundance of $L$. reginae semilineatus in areas with strong anthropic pressure may be a direct result of the abundance of prey in these environments (REINERT 1993).

Most prey were consumed head-first, a trend observed in most snakes (Mushinsky 1987, Greene 1997, Ruffato et al. 2003, Aguiar \& Di-Bernardo 2004, Albuquerque et al. 2007, Leite et al. 2007). This behavior reduces time and effort spent swallowing, reducing the resistance imposed by the limbs. It also mini- mizes the amount of time the predator is vulnerable during predation, and the likelyhood of injuries inflicted by the prey (SAzima 1989, Pinto \& Lema 2002). Prey ingested head-first were significantly larger than items ingested tail-first. Two hypotheses can explain these results: 1) the snake manipulates large prey in a way that results in head-first ingestion (GREENE 1997, Aguiar \& Di-Bernardo 2004, Albuquerque et al. 2007), or 2) bitting the prey on the anterior portion of the body is morel likely to result in successful ingestion by the snake (see VInCENT \& MORI 2008).

No correlation was found between snake head length and prey dimensions (mass, SVL and width), an unusual finding for snakes (SHINe 1991, ARNold 1993). One possible explanation for this result is the opportunistic predatory behavior of L. r. semilineatus which results in the capture of prey of differ- 
ent sizes. SHINE (1977) suggested that the capture of small prey is a strategy for reducing the risk of being injured, minimizing energy spending.

Consistent with findings for most snakes (SHINE 1991, 1994), mature females of L. reginae semilineatus have larger and wider heads (HL and HW) with respect to males. In snakes, differences in HL and HW are usually correlated with ecological divergences (SHINE 1989, 1993). Our results confirm this hypothesis, since sexual differences were observed in the size of the prey consumed (females eat larger prey than males). Such dimorphism could represent an advantage for females, which have higer reprodutive costs than males. Consumption of larger prey could help avoid intersexual competition and increase the likelihood of energetic gain (SHINE 1991, 1993).

\section{ACKNOWLEDGEMENTS}

We thank Ana Lúcia da C. Prudente, Curator of the Museu Paraense Emílio Goeldi for allowing us to dissect the snakes; Teresa C. Ávila-Pires and Marinus Hoogmoed for identifying the lizards and frogs, respectively; Alexandre B. Bonaldo for suggestions on the manuscript, and for improving the English; Conselho Nacional de Desenvolvimento Científico e Tecnológico provided financial support.

\section{LITERATURE CITED}

Aguiar, L.F.S. \& M. Di-Bernardo. 2004. Diet and feeding behavior of Helicops infrataeniatus (Serpentes: Colubridae: Xenodontinae) in southern Brazil. Studies on Neotropical Fauna and Environment 39 (1): 7-14.

Albuquerque, N.R.; U. Gallati \& M. Di-Bernardo. 2007. Diet and feeding behavior of the Neotropical parrot snake (Leptophis ahaetulla) in northern Brazil. Journal of Natural History 41 (17-20): 1237-1243.

ARnold, S.J. 1993. Foraging theory and prey-size-predator-size relations in snakes, p. 87-116. In: R.A. Seigel \& J.T. Collins (Eds). Snakes: Ecology and Behavior. New York, McGrawHill, 415p.

Ávila-PIRes, T.C.S. 1995. Lizards of Brazilian Amazonia (Reptilia: Squamata). Zoologische Verhandelingen 299: 1-706.

Ávila-Pires, T.C.S. \& M.S. Hoogmoed. 1997. The Herpetofauna, p. 389-401. In: P.L.B. LisBoA (Ed.). Caxiuanã. Belém, Museu Paraense Emílio Goeldi, 446p.

Cunha, O.R. \& F.P. Nascimento. 1978. Ofídios da Amazônia X-As cobras da região leste do Pará. Publicações avulsas do Museu Paraense Emílio Goeldi 31: 1-218.

Cunha, O.R. \& F.P. Nascimento. 1993. Ofídios da Amazônia. As cobras da região leste do Pará. Boletim do Museu Paraense Emílio Goeldi, Série Zoologia, 9: 1-191.

Dixon, J.R. 1980. The Neotropical colubrid snake genus Liophis: the generic concept. Milwaukee Public Museum, Contribution in Biology and Geology 31: 1-40.

Dixon, J.R. 1989. A Key and Checklist of the Neotropical Snake
Genus Liophis with Country List and Maps. Smithsonian Herpetological Information Service, Washington Series 79: 1-28.

Duellman, W.E. 1978. The biology of an Equatorial herpetofauna in Amazonian Ecuador. Miscellaneous Publication, Museum of Natural History 65: 1-352.

Estupiñán, R.A \& U. GALATTI. 1999. La fauna Anura en áreas com diferentes grados de intervención antrópica de la Amazonia Oriental Brasileña. Revista de La Academia Colombiana de Ciências Exactas Físicas y Naturales 23: 275-286.

Estupiñán, R.A.; J.A.R. Bernardi \& U. Galatti. 2002. La Fauna Anura, p. 541-553. In: P.L.B. LisBoA (Ed.). Caxiuanã-Populações Tradicionais, Meio Físico e Diversidade Biológica. Belém, Museu Paraense Emílio Goeldi, 734p.

GreEne HW. 1997. Snakes: the evolution of mystery in nature. Berkeley, University of California Press, 351p.

Leite, P.T.; S.F. Nunes \& S.Z. CECHIN. 2007. Dieta e uso de habitat da jararaca-do-brejo, Mastigodryas bifossatus Raddi (Serpentes, Colubridae) em domínio subtropical do Brasil. Revista Brasileira de Zoologia 24 (3): 729-734.

Lima, A.P.; W.E. Magnusson, M. Menin; L.K. Erdtmann; D.J. Rodrigues; C. Keller \& W. Hödl. 2006. Guia dos Sapos da Reserva Adolpho Ducke-Amazônia Central/Guide to the frogs of Reserva Adolpho Ducke-Central Amazonia. Manaus, 168p.

Martins M \& M.E. Oliveira. 1998. Natural history of snakes in forests of the Manaus region, Central Amazon, Brazil. Herpetological Natural History 6: 78-150.

Michaud, E.J. \& J.R. Dixon. 1989. Prey item of 20 species of the neotropical colubrid snake genus Liophis. Herpetological Review 20: 39-41.

Mushinsky, R.H. 1987. Foraging ecology, p. 302-334. In: R.A. Seigel; J.T. Collins \& S.S NovaK (Eds). Snakes: ecology and evolutionary biology. New York, MacGraw-Hill, 529p.

NHM. 2007. Avaliação e identificação das ações prioritárias para a conservação, utilização sustentável e repartição dos benefícios da Biodiversidade na Amazônia Brasileira. Núcleo de Hidrometeorologia do Pará/SECTAM/MMA. Ministério do Meio Ambiente e dos Recursos Hídricos. Available online at: http://www.para30graus.pa.gov.br/ recursos.htm [Acessed: 25.I.2007].

Pinto, R.R. \& R. Fernandes. 2004. Reproductive biology and diet of Liophis poecylogirus poecylogirus (Serpentes, Colubridae) from southeastern Brazil. Phyllomedusa 3: 9-14.

Pinto, C.C. \& T. Lema. 2002. Comportamento alimentar e dieta de serpentes do gênero Boiruna e Clelia (Serpentes, Colubridae). Iheringia, Série Zoologia, 92: 9-19.

PizzatTo, L. \& O.A.V. MARQues. 2006. Interpopulational variation in sexual dimorphism, reproductive output, and parasitism of Liophis miliaris (Colubridae) in the Atlantic forest of Brazil. Amphibia- Reptilia 27: 37-46.

ReinerT, H.K. 1993. Habitat selection in snakes, p. 201-240. In: R.A. Seigel; J.T. Collins \& S.S Novak (Eds). Snakes: ecology 
and evolutionary biology. New York, MacGraw-Hill, 529p.

Ruffato, R.; M. Di-Bernardo \& G.F. Maschio. 2003. Dieta de Thamnodynastes strigatus (Serpentes, Colubridae) no sul do Brasil. Phyllomedusa 2: 27-34.

SAzImA, I. 1989. Comportamento alimentar de jararaca, Bothrops jararaca: Encontros provocados na natureza. Ciência e Cultura 41: 500-505.

SHINE, R. 1977. Habitats, diets, and sympatry in snakes: A study from Australia. Canadian Journal of Zoology 55: 11181128.

SHINE, R. 1989. Ecological causes for the evolution of sexual dimorphism: A review of the evidence. Quarterly Review of Biology 64: 419-61.

Shine, R. 1991. Why do larger snakes eat larger prey items? Functional Ecology 5: 493-502.

SHINe, R. 1993. Sexual dimorphism in snakes, p. 49-86. In: R.A. Seigel; J.T. Collins \& S.S NovaK (Eds). Snakes: ecology and evolutionary biology. New York, MacGraw-Hill, 529p.

ShIne, R. 1994. Sexual size dimorphism in snakes revisited. Copeia 1994 (2): 326-346.

SolÉ, M. \& A. KwEt. 2003. Liophis jaegeri: diet. Herpetological Review 34: 69.

SoKAL, R.R. \& F.J. Rohlf. 1981. Biometry. New Your, Freeman, $2^{\text {nd }}, 859 \mathrm{p}$.

Vincent, S.E. \& A. Mori. 2008. Determinants of feeding performance in free-ranging pit-vipers (Viperidae: Ovophis okinavensis): key roles for head size and body temperature. Biological Journal of the Linnean Society 93: 53-62.

VITT, L.J. 1983. Ecology of an anuran-eating guild of terrestrial tropical snakes. Herpetologica 39: 52-56.

VitT, L.J. \& L.D. VANGILDER. 1983. Ecology of a snake community in northeastern Brazil. Amphibia-Reptilia 4: 273-296.

ZAR, J.H. 1999. Biostatistical analysis. Upper Saddle River, Prentice-Hall, 623p.

Appendix 1. Material examined from State of Pará.

MPEG 14212 (Acará), MPEG 19331 (Anajás), MPEG 114, MPEG 419, MPEG 529, MPEG 5454, and MPEG 18571 (Ananindeua), MPEG 575, MPEG 576, MPEG 577, MPEG 578, MPEG 579, MPEG 580, MPEG 808, MPEG 2569, MPEG 2570, MPEG 2571, MPEG 2572, MPEG 2573, MPEG 2574, MPEG 2575, MPEG 2576, MPEG 2586, MPEG 9991, MPEG 10005, and MPEG 13089 (Augusto Corrêa), MPEG 316, MPEG 2043, MPEG 3272, MPEG 15399, MPEG 16410, MPEG 16706, MPEG 16837, MPEG 17639, MPEG 17712, MPEG 18446, MPEG 18447, MPEG 18454, MPEG 18463, MPEG 18464, MPEG 18467, MPEG 18528, MPEG 18604, MPEG 18632, MPEG 18667, MPEG 18819, MPEG 18982, MPEG 18987, MPEG 19315, MPEG 19403, MPEG 19981, MPEG 20181, MPEG 20405, MPEG 20798, MPEG 21075, MPEG 21287, and MPEG 21288 (Belém), MPEG 8611, MPEG 8624, MPEG 10923, MPEG 11857, MPEG 13321, and MPEG 18519 (Benevides), MPEG 2489, MPEG 2493, MPEG 7897, MPEG 7951, MPEG 7970, MPEG 7995, MPEG 11225, MPEG 11346, MPEG 11351, MPEG 11395, MPEG 11399, MPEG 13036, MPEG 16018, MPEG 16021, and MPEG 20774 (Bragança), MPEG 17366 (Breves), MPEG 3253, MPEG 3263, MPEG 18165, and MPEG 18321 (Cachoeira do Arari), MPEG 20630 (Canaã dos Carajás), MPEG 15447 (Capanema), MPEG 8830, MPEG 9606, MPEG 9608, MPEG 9611, MPEG 9621, MPEG 9622, MPEG 10668, MPEG 11036, MPEG 11038, MPEG 12153, and MPEG 12991 (Capitão Poço), MPEG 538, MPEG 1161, MPEG 2695, MPEG 3324, MPEG 3325, MPEG 3327, MPEG 4020, MPEG 4033, MPEG 4766, MPEG 4767, MPEG 8649, MPEG 9451, MPEG 9456, MPEG 18525, and MPEG 20509 (Castanhal), MPEG 886, MPEG 898, MPEG 917, MPEG 920, MPEG 927, and MPEG 956 (Igarapé-açú), MPEG 1192, and MPEG 1197 (Inhangapi), MPEG 7464, MPEG 7475, MPEG 9482, and MPEG 16603 (Marabá), MPEG 19952, MPEG 19989, MPEG 20048, MPEG 20077, MPEG 20242, and MPEG 20447 (Melgaço), MPEG 1277, MPEG 2167, MPEG 4214, MPEG 4987, MPEG 6141, MPEG 7010, MPEG 18864, and MPEG 19405 (Ourém), MPEG 1410, MPEG 1413, MPEG 1417, MPEG 2589, and MPEG 4608 (Peixe-Boi), MPEG 609, MPEG 6032, MPEG 18189, and MPEG 18190 (Santa Bárbara), MPEG 123, MPEG 406, MPEG 407, MPEG 409, and MPEG 410 (Santarém), MPEG 3482, MPEG 4795, MPEG 5923, and MPEG 7064 (Santarém Novo), MPEG 18432, and MPEG 18433 (São Félix do Xingu), MPEG 1447, MPEG 3307, and MPEG 5697 (Santo Antônio do Tauá), MPEG 19854 (São Geraldo do Araguaia), MPEG 9476, and MPEG 16684 (Tucuruí), MPEG 18449, and MPEG 21274 (Vigia), MPEG 1025, MPEG 1035, MPEG 1057, MPEG 1063, MPEG 1346, MPEG 1349, MPEG 1355, MPEG 5991, MPEG 6008, MPEG 9838, MPEG 14157, MPEG 14496, MPEG 14518, MPEG 16271, MPEG 16272, MPEG 16281 (Viseu).

Submitted: 06.I.2009; Accepted: 19.I.2010.

Editorial responsibility: Ana Lúcia da Costa Prudente 